IRA-International Journal of Management \& Social Sciences

ISSN 2455-2267; Vol.07, Issue 01 (2017)

Pg. no. 1-13

Institute of Research Advances

https://research-advances.org/index.php/RAJMSS

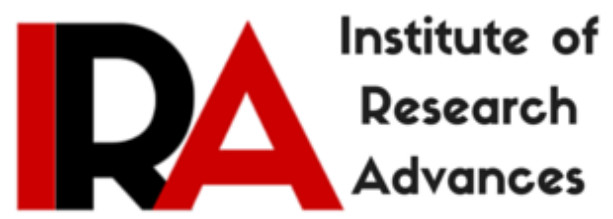

\title{
A Study on the Positive Potential of Demonetization and Digital Payment System to improve Service Quality of Indian Banks
}

\author{
Sumanta Mukhopadhyay \\ Educational Consultant, NIIT Imperia (National Institute of Information Technology), \\ Durgapur, West Bengal, India. \\ Previously: Assistant Professor- Marketing, DSMS Group of Institutions, Durgapur \& \\ DSMS Business School, Durgapur-713 212, West Bengal, India.
}

Type of Review: Peer Reviewed.

DOI: http://dx.doi.org/10.21013/jmss.v7.n1.p1

\section{How to cite this paper:}

Mukhopadhyay, S. (2017). A Study on the Positive Potential of Demonetization and Digital Payment System to improve Service Quality of Indian Banks. IRA-International Journal of Management \& Social Sciences (ISSN 2455-2267), 7(1), 1-13. doi:http://dx.doi.org/10.21013/jmss.v7.n1.p1

(C) Institute of Research Advances (cc) EY-NC

This work is licensed under a Creative Commons Attribution-Non Commercial 4.0 International License subject to proper citation to the publication source of the work.

Disclaimer: The scholarly papers as reviewed and published by the Institute of Research Advances (IRA) are the views and opinions of their respective authors and are not the views or opinions of the IRA. The IRA disclaims of any harm or loss caused due to the published content to any party. 


\begin{abstract}
The present wave of Demonetization and Digital Payment System towards a Cashless Economy demands that our Commercial banks provide superior customer service as one of the biggest provider of banking and financial services in our urban and rural hinterland. Loyal customer base can only be created through delivering Customer Delight. But the crux of the matter is that to achieve better performance, the Indian banks, both private and public, need to provide Service Quality. Different authors in India have tried for introspection of the service quality through different constructs and dimensions in the banking sector in India. Here in this paper, we will try to investigate different works related to banking done in India, the different dimensions researched so far and the positive potential of Demonetization and Digital to make SERVQUAL Dimensions more effective towards delivering better customer satisfaction.
\end{abstract}

Key Words: Customer Expectation, Customer Perception, Customer Satisfaction, Customer Delight, Service Quality, Demonetization, Digital Transaction, Cashless Payment System

\title{
INTRODUCTION:
}

\section{"Truth is ever to be found in simplicity and not in the multiplicity and confusion of things"} ISAAC NEWTON

The most striking change in the structure of the developed economies in the latter half of the twentieth century has been the change of emphasis from the manufacture of the physical goods to the production of intangible services. In the USA, the percentage of workers engaged in the service sector rose from $30 \%$ in 1990 to $80 \%$ by 1995 and in the other developed countries too, including those in Europe, and Japan, the significance of the service sector has increased immensely. Even manufacturing units have come to realize increasingly, that producing goods of very high quality is no longer a source of differential advantage; it is a rudimentary requirement in order to sustain in the marketplace. The competitiveness and value of the products that they sell are likely to emanate from the attendant services offered with them rather than the goods' physical properties (Rust et. al., 1996). There is a plethora of reasons for the increasing importance of services in the developed economies. One significant reason which has driven the growth of the service economy in the West is the deregulation by the Government of service sectors like banking, insurance, airlines and telecommunications that was at one time constrained by law from developing new products or opening new markets. Yet another major tributary to the growth of the service industries has been the increasing demand for healthcare, spurred primarily by the aging of the population as well as the increasing acceptance of marketing by numerous professional groups such as doctors.

During the last few decades, the hugely acknowledged significance of service quality resulted in a plethora of attempts by researchers, practitioners and managers, aimed at its conceptualization and measurement. However, this has been proven to be a tough job, causing long-lasting debates among the people involved, mainly due to the intangible property of services and problems cropping up from the simultaneous production and consumption of a service (Carman, 1990). Despite this debate, it can be put forward that there is a convergence towards the view of Parasuraman et. al. (1988, p. 16) that customer perceived service quality, is a 'global judgment or attitude, relating to the superiority of the service'. 


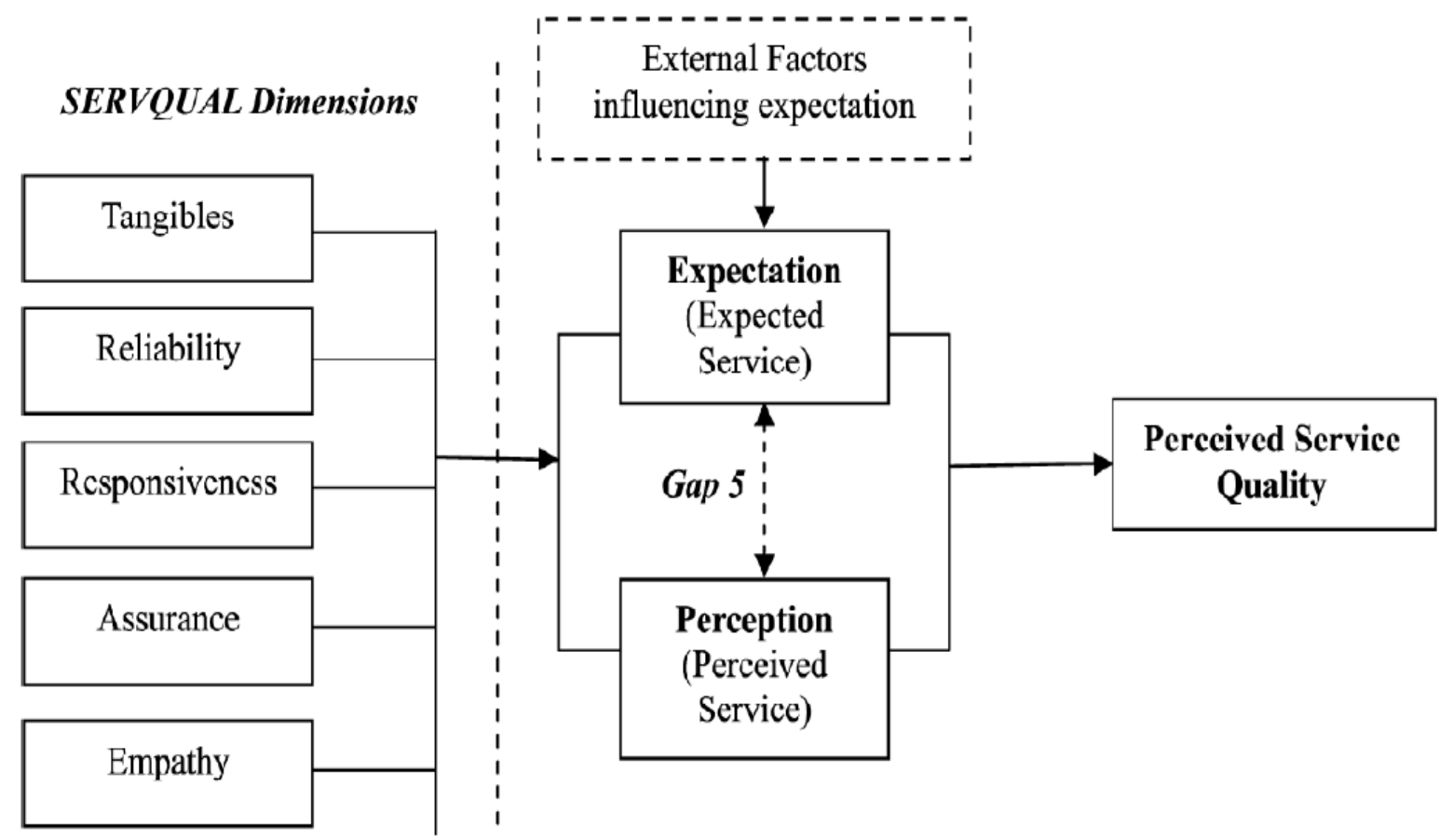

\section{Figure: SERVQUAL Dimensions and Study of Service Quality Gaps}

Several measuring instruments have been developed, aiming to encapsulate and explain the service quality dimensions. There is hardly any doubt that, among these, SERVQUAL is the most popular, a fact confessed even by its critics (e.g. Asubonteng et. al., 1996). SERVQUAL has been developed in a series of phases leading to consecutively more sophisticated versions (Parasuraman et. al., 1985, 1988, 1991, 1994). In the most commonly applied version (Parasuraman et. al., 1988), service quality is framed as the gap between customer expectations and perceptions. The 22 items of this instrument are categorized into:

- Reliability: The ability to perform the promised service dependably and accurately.

- Tangibles: The appearance of physical facilities, equipment, personnel and communications materials.

- Responsiveness: The willingness to help customers and to provide prompt service.

- Assurance: The knowledge and courtesy of employees and their ability to convey trust and confidence.

- Empathy: The provision of caring, individualized attention to customers. 


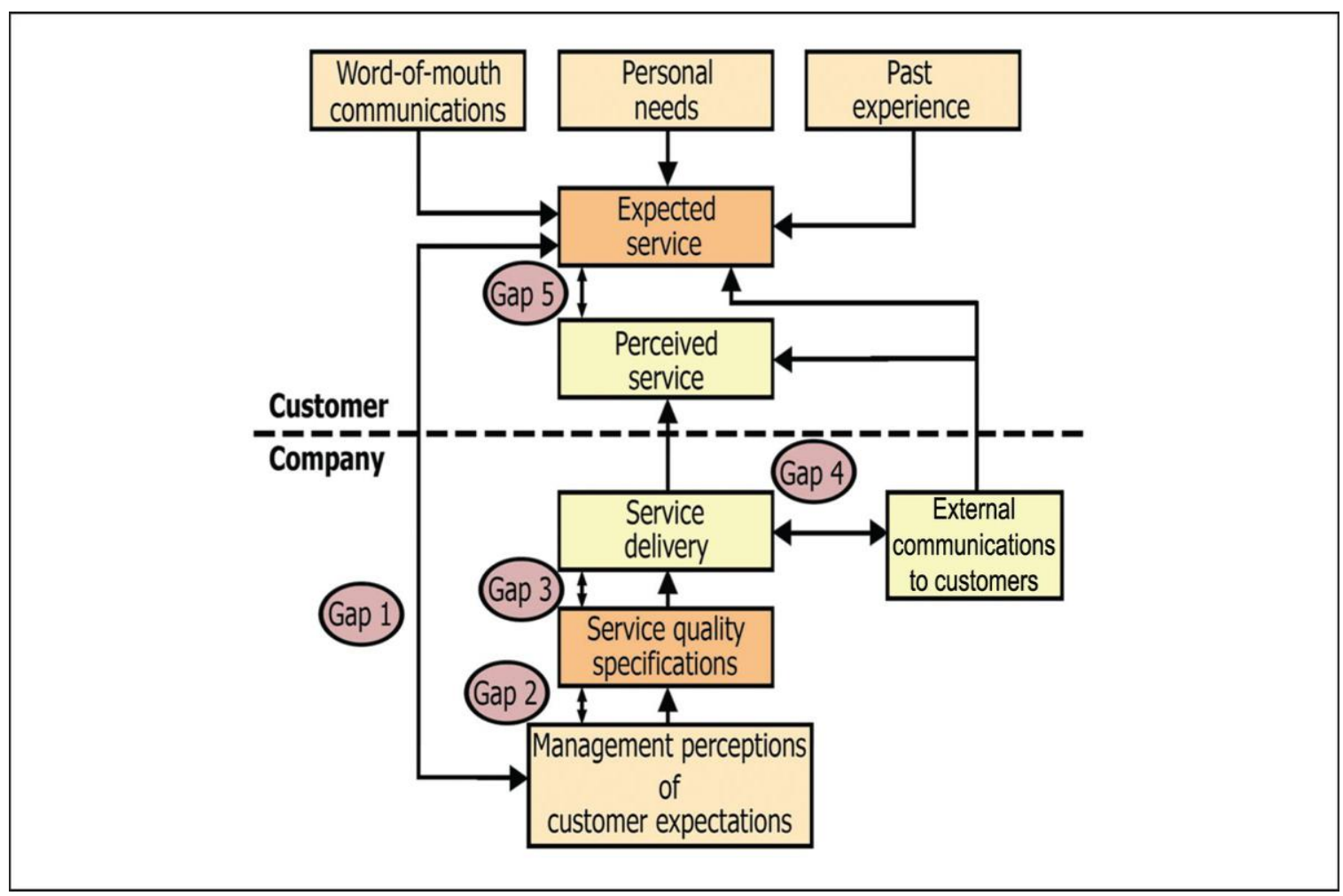

Figure: SERVQUAL Model and Service Quality Gaps (Expectation vs. Perception)

\section{REVIEW OF CONTEMPORARY INDIAN LITERATURE:}

Many research studies have been done worldwide on Service Quality. A part of that collection is research done by Indian researchers. Again, some of those researches are on different areas of service industry and the rest are on banking. Here we will try to deal with some work done on banking sector in India with the application of SERVQUAL model. The studies are small in number but they represent authors whose works are very recent and so it demands some special emphasis as this will lead to further research that may change the banking operations in India and even may be worldwide. We will try to advance through listing the authors, dimensions they have studied and the resultant findings in a tabular form. The list will help us in encapsulating the service quality and its relevance in Indian banking operations. The table is as below:

\begin{tabular}{|c|c|c|}
\hline Researchers & Dimensions & Findings of the Study \\
\hline $\begin{array}{l}\text { Alok Kumar Rai } \\
\text { [Associate } \\
\text { Professor, Faculty } \\
\text { of Management } \\
\text { Studies, Banaras } \\
\text { Hindu University, } \\
\text { Varanasi, India] }\end{array}$ & $\begin{array}{l}\text { 1.Tangibility } \\
\text { 2.Competence } \\
\text { 3.Responsiveness } \\
\text { 4.Safety } \\
\text { 5.Communication } \\
\text { 6.Understanding } \\
\text { customers }\end{array}$ & $\begin{array}{l}\text { The research was on two large Indian banks reveals that } \\
\text { customers are not very happy. SBI is performing badly in } \\
\text { communication, responsiveness, competence and tangibility } \\
\text { whereas its strength lies in understanding customers and safety } \\
\text { dimension. HDFC is lacking in responsiveness, competence and } \\
\text { understanding customers but strong in tangibility, safety and to a } \\
\text { certain extent communication. }\end{array}$ \\
\hline $\begin{array}{l}\text { T. Vanniarajan } \\
\text { [Reader, Business } \\
\text { Administration, }\end{array}$ & $\begin{array}{l}\text { Trustworthiness } \\
\text { Competence } \\
\text { Service promptness }\end{array}$ & $\begin{array}{l}\text { In this research done in Madurai city, it was seen that a bank can } \\
\text { create a distinct image by providing differentiated service quality } \\
\text { than their competitors. Telephone banking could include }\end{array}$ \\
\hline
\end{tabular}




\begin{tabular}{|c|c|c|}
\hline $\begin{array}{l}\text { N.M.S.S.V.N. } \\
\text { College, Madurai, } \\
\text { TN, India] } \\
\text { K.Nainamohamed } \\
\text { [SS Lecturer in } \\
\text { Commerce, Dr. } \\
\text { ZakirHussian } \\
\text { College, Ilayankudi, } \\
\text { Sivagangai, TN, } \\
\text { India] }\end{array}$ & $\begin{array}{l}\text { Latest technology } \\
\text { High interest rate } \\
\text { Drive-in facilities } \\
\text { Convenient timing } \\
\text { Launch new service } \\
\text { Low mortgage rate } \\
\text { Helping employees } \\
\text { Transparency } \\
\text { Accuracy } \\
\text { Phone banking } \\
\text { Overdraft privileges } \\
\text { Courteousness }\end{array}$ & $\begin{array}{l}\text { additional innovative banking services. While offering specified } \\
\text { service banks should separate themselves from the pack. Print } \\
\text { advertisement should be more preferred than television and radio } \\
\text { advertising. Banks might benefit from a differentiating effort } \\
\text { based on a move toward the "first in new services" attribute. The } \\
\text { banks which concentrate on providing "error-free services", } \\
\text { "provide accurate statements", trustworthy and competent } \\
\text { employees, should extend their focus on providing a } \\
\text { "comfortable environment to do business. Banks should be very } \\
\text { courteous, friendly and transparent in order to retain its present } \\
\text { position. }\end{array}$ \\
\hline $\begin{array}{l}\text { Garima } \\
\text { Mathur\&Anindita } \\
\text { Chakraborty } \\
\text { [Prestige Institute of } \\
\text { Management, } \\
\text { Gwalior], Silky } \\
\text { Vigg, [Jagannath } \\
\text { International-New } \\
\text { Delhi] Umesh } \\
\text { Holani, [Jiwaji } \\
\text { Univ. Gwalior] }\end{array}$ & $\begin{array}{l}\text { 1.Customized banking } \\
\text { solutions } \\
\text { 2.Customer } \\
\text { satisfaction } \\
\text { 3.Banking facilities } \\
\text { 4.Bank policies } \\
\text { 5.Satisfaction with } \\
\text { services } \\
\text { 6.Online solutions } \\
\text { Other facilities }\end{array}$ & $\begin{array}{l}\text { The paper opines that a key competitive issue for the banks today } \\
\text { is to manage their existing customer relationship by developing } \\
\text { their product range and service quality to meet the increasingly } \\
\text { sophisticated needs of the different classes of customers. This } \\
\text { paper explores the service quality perception and expectations of } \\
\text { corporate customers towards their bankers. The results show that } \\
\text { there was a significant difference between service quality } \\
\text { perception of corporate customer towards private and public } \\
\text { banks. }\end{array}$ \\
\hline $\begin{array}{lr}\text { Monica } & \text { Bedi, } \\
\text { Faculty, University } \\
\text { Business School, } \\
\text { Panjab University, } \\
\text { Chandigarh, India. }\end{array}$ & $\begin{array}{l}\text { 1.Goods'Knowledge } \\
\text { 2.Parking space } \\
\text { 3.Convenient hours } \\
\text { 4.Personal attention } \\
\text { 5.Sincere interest } \\
\text { 6.Prompt service } \\
\text { 7.Office Decorum } \\
\text { 8.Visually appealing } \\
\text { signs, symbols, logo } \\
\text { 10.Loan facilities }\end{array}$ & $\begin{array}{l}\text { Investigated relationship between service quality, overall } \\
\text { customer satisfaction and behavioral intentions across public and } \\
\text { private banks in India. The findings were that service quality is a } \\
\text { significant determinant of customer satisfaction irrespective of } \\
\text { public and private sector banks. Different dimensions of service } \\
\text { quality were found to be statistically significant. Customer } \\
\text { satisfaction was found to be strongly associated with propensity } \\
\text { to recommend. The study will help banks to redefine their } \\
\text { corporate image to one that is customer-focused and driven by } \\
\text { service quality. }\end{array}$ \\
\hline $\begin{array}{l}\text { S. Manimaran } \\
\text { [Professor, } \\
\text { Department } \\
\text { Management } \\
\text { Studies, PSNAET, } \\
\text { Dindigul, TN, India] }\end{array}$ & $\begin{array}{l}\text { 1.Reliability } \\
\text { 2.Responsiveness } \\
\text { 3.Knowledge and } \\
\text { Recovery } \\
\text { 4.Tangibles } \\
\text { 5.Perceived data } \\
\text { 6.Customer } \\
\text { satisfaction } \\
\text { 7.Customer loyalty }\end{array}$ & $\begin{array}{l}\text { Studied linkage between service quality and customer loyalty in } \\
\text { Indian retail banking. Service quality dimensions lead to } \\
\text { customer satisfaction and hence customer loyalty. The structural } \\
\text { equation model reveals that there is no significant direct linkage } \\
\text { between service quality and customers' loyalty; but service } \\
\text { quality has significant indirect impact on customers' loyalty } \\
\text { through customers' satisfaction. Hence bank managers need to } \\
\text { develop a systematic assessment program to monitor service } \\
\text { quality and customer satisfaction. Once service culture is } \\
\text { established, that will lead to customer satisfaction. And customer } \\
\text { satisfaction leads to customers' loyalty. }\end{array}$ \\
\hline
\end{tabular}




\section{A META-ANALYSIS WITH SERVQUAL ON LEADING PSU BANK:}

OBJECTIVE: To do Investigative Study among the Customers of a leading PSU Bank to find out the Efficacy and Comparative Importance of five Service Quality Dimensions, namely, Tangibles, Reliability, Responsiveness, Assurance and Empathy:

Study of Expected Service Quality: Based on the experiences as a customer in a bank, respondents were requested to think about the kind of bank that would deliver excellent quality of service. They have been asked to think about the kind of bank in which they would like to receive service. They showed the extent to which they think such a bank would possess the feature described by each of the 22 statements (containing five dimensions Tangibles, Reliability, Responsiveness, Assurance and Empathy). If they felt a feature is not at all essential for excellent banks such as the one they had in mind, they were asked to circle the number 1 and if they felt a feature absolutely essential for excellent banks, they would circle 7. If their feelings were less strong, they would circle one of the numbers in the middle. There was no right or wrong numbers- all we were interested in was the number that truly reflects their feelings regarding banks that would deliver excellent quality of service.

Study of Perceived Service Quality: Next a set of statements relate to their feelings about the bank they have attended, here SBI. For each statement it was requested to show the extent to which they believe the bank has the feature described by the statement. Once again, circling 1 means that they strongly disagree that the bank they have attended has this feature and circling a 7 means that they strongly agree. They may circle any of the numbers in the middle that show how strong your feelings are. There was no right or wrong answers - all we were interested in was a number that best shows their perceptions about the bank they have dealt with.

Finding out SERVQUAL Scores: We will try to find out the gaps by deriving SERVQUAL Scores, both weighted and un-weighted as also total SERVQUAL Scores by dividing with N (30) number of respondents. Weights were given to five dimensions (totaling 100) and each respondent was to rate the dimensions as the most important feature, the second most important feature and the least important one. Some unique suggestions have also come from the respondents which hold the promise of increasing service quality and customer satisfaction.

\section{SERVQUAL WEIGHTED SCORES}

SERVQUAL Dimension ScoreX Importance Weight $=$ Weighted Score

Average Tangible

Average Reliability

Average Responsiveness

Average Assurance

Average Empathy

TOTAL

AVERAGE (= Total / 5) WEIGHTED SERVQUAL SCORE

Table-1: SERVQUAL WEIGHTED SCORES

\begin{tabular}{|c|c|c|c|c|c|c|}
\hline Respondent & Tangibles & Reliability & Responsiveness & Assurance & Empathy & $\begin{array}{l}\text { Weighted } \\
\text { Score }\end{array}$ \\
\hline R-1 & $0.10 * 2.75=0.275$ & $0.30 * 2.20=0.66$ & $0.25 * 1.25=0.3125$ & $0.20 * 1.5=0.30$ & $0.15 * 2.4=0.36$ & 1.9075 \\
\hline R-2 & $0.10 * 2.5=0.25$ & $0.15 * 1.8=0.27$ & $0.20 * 2=0.40$ & $0.30 * 0.25=0.075$ & $0.25 * 1.6=0.40$ & 1.3950 \\
\hline R-3 & $0.15 * 1=0.15$ & $0.10 * 0=0.00$ & $0.30 * 1.50=0.45$ & $0.20 * 0=0.00$ & $0.25 * 1.2=0.30$ & 0.9000 \\
\hline R-4 & $0.25 * 2.5=0.625$ & $0.10 * 1.8=0.18$ & $0.15 * 2=0.30$ & $0.20 * 0.25=0.05$ & $0.30 * 1.6=0.48$ & 1.6350 \\
\hline
\end{tabular}


IRA-International Journal of Management \& Social Sciences

\begin{tabular}{|c|c|c|c|c|c|c|}
\hline R-5 & $0.20 * 1=0.20$ & $0.25 * 0=0.00$ & $0.30 * 1.5=0.45$ & $0.15 * 0=0.00$ & $0.10 * 1.2=0.12$ & 0.7700 \\
\hline R-6 & $0.10 * 1=0.10$ & $0.30 * 0=0.00$ & $0.25 * 0.5=0.125$ & $0.15 * 0=0.00$ & $0.20 * 0.8=0.16$ & 0.3850 \\
\hline R-7 & $0.20 * 0=0.00$ & $0.20 * 0=0.00$ & $0.20 * 0=0.00$ & $0.20 * 0=0.00$ & $0.20 * 0=0.00$ & 0.0000 \\
\hline $\mathbf{R - 8}$ & $0.15 * 1=0.15$ & $0.20 * 2=0.40$ & $0.25 * 3=0.75$ & $0.10 * 1.75=0.175$ & $0.30 * 4.4=1.32$ & 2.7950 \\
\hline R-9 & $0.30 * 1.75=0.525$ & $0.20 * 0.6=0.12$ & $0.25 * 0.5=0.125$ & $0.10 * 0.5=0.05$ & $0.15 * 1.4=0.21$ & 1.0300 \\
\hline R-10 & $0.15 * 0=0.00$ & $0.30 * 1.6=0.48$ & $0.25 * 1=0.25$ & $0.20 * 0.25=0.05$ & $0.10 * 1.6=0.16$ & 0.9400 \\
\hline R-11 & $0.10 * 2=0.20$ & $0.30 * 0=0.00$ & $0.25 * 0.5=0.125$ & $0.20 * 0.75=0.15$ & $0.15 * 1.8=0.27$ & 0.7450 \\
\hline R-12 & $0.10 * 1.75=0.175$ & $0.30 * 0=0.0$ & $0.25 * 0.5=0.125$ & $0.20 * 0.75=0.15$ & $0.15 * 1.8=0.27$ & 0.7200 \\
\hline R-13 & $0.10 * 3.5=0.35$ & $0.30 * 1.2=0.36$ & $0.25 * 1.25=0.3125$ & $0.20 * 0=0.0$ & $0.15 * 1.4=0.21$ & 1.2325 \\
\hline R-14 & $0.10 * 1.5=0.15$ & $0.30 * 3.4=1.02$ & $0.25 * 2=0.50$ & $0.15 * 1=0.15$ & $0.20 * 2.2=0.44$ & 2.2600 \\
\hline R-15 & $0.20 * 0=0.00$ & $0.15 * 0=0.00$ & $0.25 * 0=0.00$ & $0.10 * 0=0.00$ & $0.30 * 0=0.00$ & 0.0000 \\
\hline R-16 & $0.10 * 1.5=0.15$ & $0.25 * 0.6=0.15$ & $0.30 * 1.25=0.375$ & $0.20 * 0=0.00$ & $0.15 * 1.2=0.18$ & $\mathbf{0 . 8 5 5 0}$ \\
\hline R-17 & $0.10 * 1.5=0.15$ & $0.25 * 0.4=0.10$ & $0.30 * 1.25=0.375$ & $0.20 * 0=0.00$ & $0.15 * 1.2=0.18$ & 0.8050 \\
\hline R-18 & $0.10 * 1.5=0.15$ & $0.25 * 0.6=0.15$ & $0.30 * 1.25=0.375$ & $0.20 * 0=0.00$ & $0.15 * 1.2=0.18$ & 0.8550 \\
\hline R-19 & $0.10 * 2.5=0.25$ & $0.25 * 1.8=0.45$ & $0.30 * 2=0.60$ & $0.15 * 1.75=0.2625$ & $0.20 * 2.2=0.44$ & 2.0025 \\
\hline R-20 & $0.10 * 2.5=0.25$ & $0.25 * 2.6=0.65$ & $0.30 * 2.75=0.825$ & $0.20 * 1.25=0.25$ & $0.15 * 3=0.45$ & 2.4250 \\
\hline R-21 & $0.10 * 2=0.20$ & $0.25 * 1=0.25$ & $0.30 * 1=0.30$ & $0.15 * 0.5=0.075$ & $0.20 * 1.6=0.32$ & 1.1450 \\
\hline R-22 & $0.20 * 2=0.40$ & $0.25 * 1.8=0.45$ & $0.15 * 2.5=0.375$ & $0.30 * 1.25=0.375$ & $0.10 * 2.4=0.24$ & 1.8400 \\
\hline R-23 & $0.10 * 0.25=0.025$ & $0.25 * 0.2=0.050$ & $0.20 * 0=0.00$ & $0.30 * 0=0.00$ & $0.15 * 0.6=0.09$ & 0.1650 \\
\hline R-24 & $0.10 * 1.75=0.175$ & $0.25 * 1=0.25$ & $0.30 * 0.5=0.15$ & $0.15 * 0=0.00$ & $0.20 * 0=0.00$ & 0.5750 \\
\hline R-25 & $0.10 * 0=0.00$ & $0.15 * 2=0.30$ & $0.25 * 3=0.75$ & $0.3 * 1.75=0.525$ & $0.20 * 2.4=0.48$ & 2.0550 \\
\hline R-26 & $0.10 * 1.75=0.175$ & $0.30 * 2.8=0.84$ & $0.25 * 2.5=0.625$ & $0.15 * 1.75=0.2625$ & $0.20 * 3.2=0.64$ & 2.5425 \\
\hline R-27 & $0.10 * 0.5=0.05$ & $0.30 * 0.6=0.18$ & $0.25 * 0.5=0.125$ & $0.20 * 0.5=0.01$ & $0.15 * 2.4=0.36$ & 0.7250 \\
\hline R-28 & $0.10 * 0=0.00$ & $0.30 * 0.4=0.12$ & $0.25 * 0=0.00$ & $0.15 * 0=0.00$ & $0.20 * 2.2=0.44$ & 0.5600 \\
\hline R-29 & $0.10 * 0=0.00$ & $0.30 * 0.6=0.18$ & $0.25 * 0.5=0.125$ & $0.20 * 0.25=0.05$ & $0.15 * 0.2=0.03$ & 0.3850 \\
\hline R-30 & $0.10 * 0.25=0.025$ & $0.30 * 0.4=0.12$ & $0.25 * 0.75=0.1875$ & $0.15 * 0=0.00$ & $0.20 * 0=0.00$ & 0.3325 \\
\hline
\end{tabular}

\section{TOTAL SERVQUAL SCORES:-}

It is calculated by the formula: Totaling the Scores

No. of respondents

So, total SERVQUAL Score $=34.9825 / 30(\mathrm{~N}=30)$.

$$
=1.166083333=1.17 \text { (approx.) }
$$

\section{The Relative Importance of Service Quality Dimensions:-}

\section{Most Important Dimension:}

It has been seen that most of the respondents think Reliability to be the most important dimension, followed by Responsiveness, Assurance, Empathy and Tangibles. 


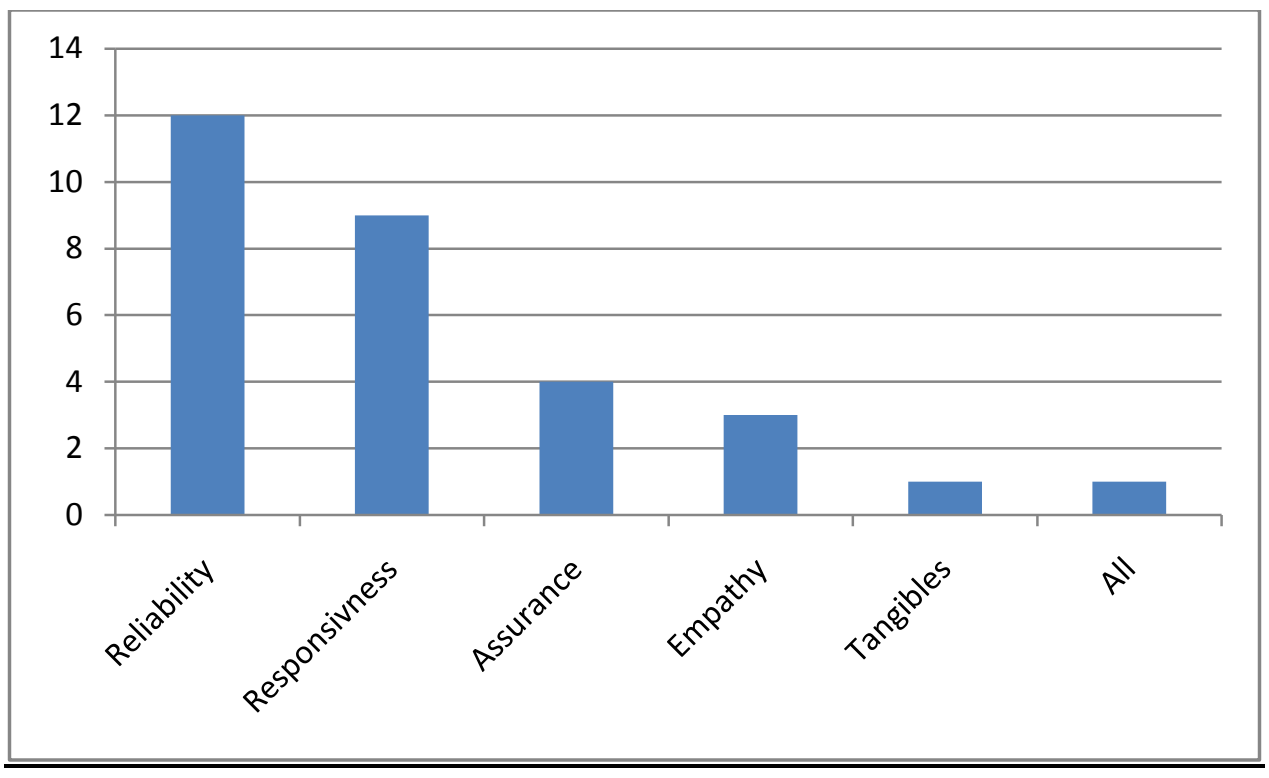

\section{Second Most Important Dimension:}

It has been seen that most of the respondents think Responsiveness, to be the second most important dimension, followed by Reliability, Empathy and Tangibles.

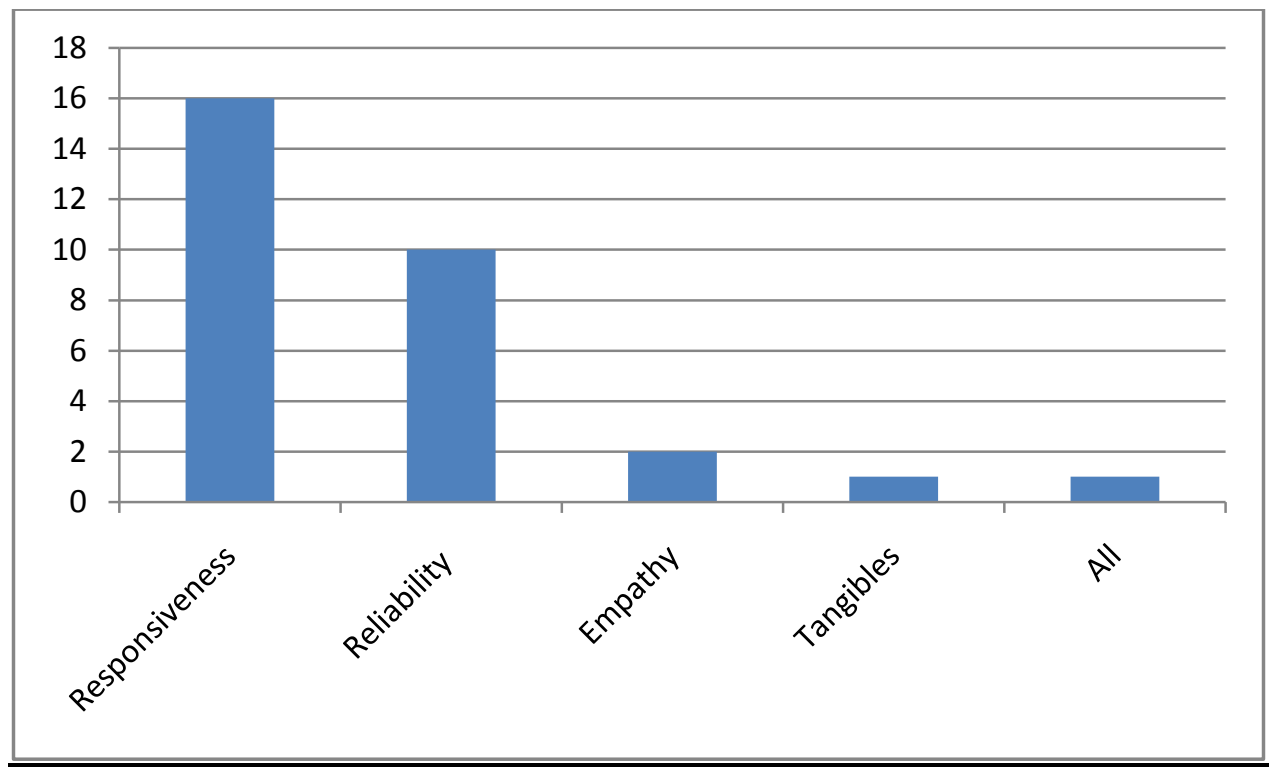

\section{Least Important Dimension:}

It has been seen that most of the respondents think Tangibles, to be the least important dimension, followed by Reliability, Empathy and Assurance. 


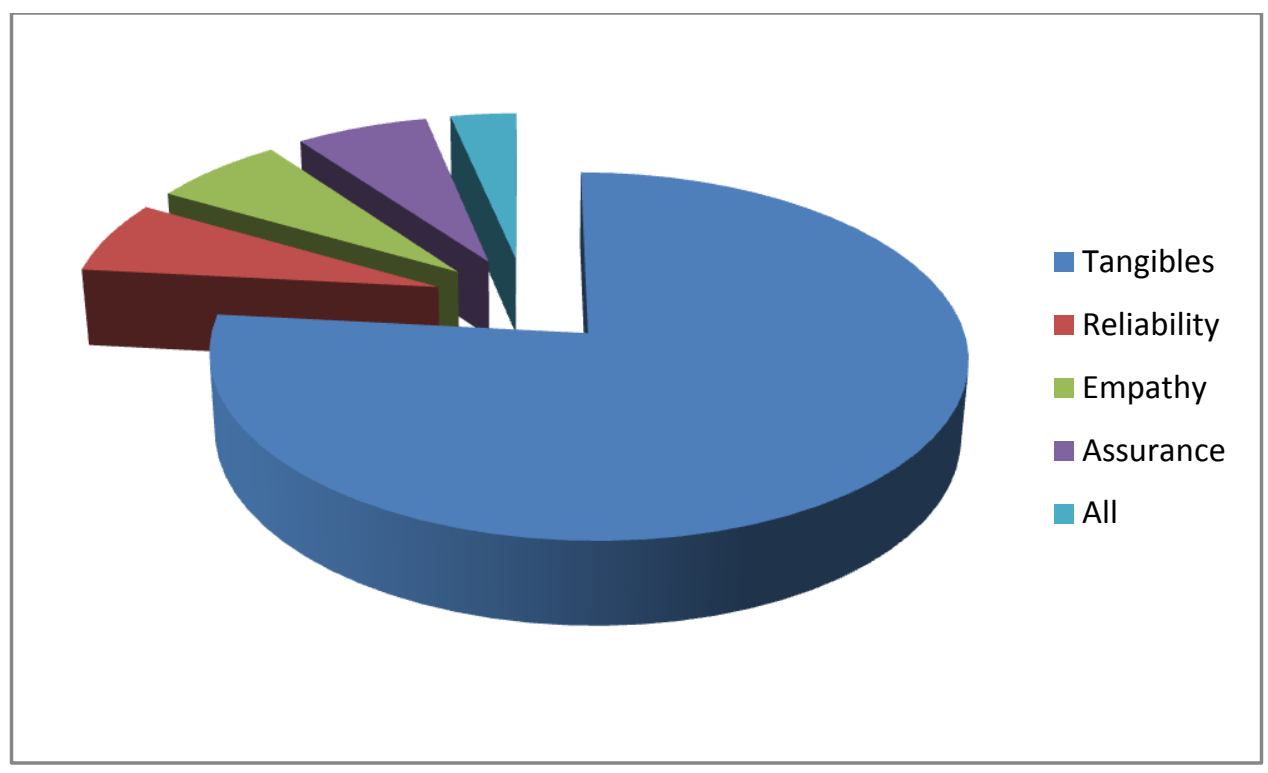

\section{Potential of Demonetization and Digital in Improved SERVQUAL:}

Our country is now moving towards a cashless environment after demonetization. The initial awe and confusion is giving way to a flurry of concerns. There are huge benefits in Digital and SERVQUAL and if amalgamated, they can improve in SERVICE Quality Dimensions (Reliability, Responsiveness, Assurance, Empathy and Tangibles) and amalgamate the best of both worlds - Digital and SERVQUAL.

\section{ADVANTAGES OF GOING CASHLESS:}

There are a number of advantages, like (1)Convenience: (The ease of conducting financial transactions), (2)Discounts (The recent waivers, cuts and freebies, cash back offers, reward points, loyalty benefits and discounts by mobile wallets), (3) Tracking spends:(It will be easy for people to keep track of their spending),(4)Benefits for the trader / seller: (Ease of payment),(5)Budget discipline: (The written record will help you keep tabs on your spending and this will result in better budgeting), and (6)Lower risk: (If stolen, it is easy to block a credit card or a mobile wallet remotely, but it's impossible to get your cash back).

\section{IT'S TIME TO GO DIGITAL AND GET DISCOUNTS:}

\begin{tabular}{|l|l|}
\hline Particulars & Discounts \\
\hline Service Tax & Waiver of service tax of 15\% on digital transactions up to Rs. 2000/ \\
\hline Fuel & $0.75 \%$ discount on purchase of fuel by credit / debit cards, mobile or e- wallets \\
\hline Rail Tickets & $0.5 \%$ discount on monthly and seasonal suburban railway tickets from 1 Jan'17 \\
\hline Rail catering & $5 \%$ Discount on digital payment - railway catering, accommodation, retiring room \\
\hline Highway toll & $10 \%$ discount on NH toll payment via RFID or fast-tags in 2016-17 \\
\hline Insurance & $\begin{array}{l}10 \% \text { discount by govt. general insurers on premium paid online via their portals, } \\
8 \% \text { discount on new LIC policies bought online }\end{array}$ \\
\hline
\end{tabular}




\begin{tabular}{|l|l|}
\hline PoS & Rs. 100/- a month is max. rent that PSU Banks can charge for PoS Terminals \\
\hline RuPay & Kisan Credit Card holder to get RuPayKisan Card \\
\hline
\end{tabular}

\section{CORPORTAE SOCIAL RESPONSIBILITY (CSR) \& YOUTH PARTICIPATION}

After demonetization, low wage earners and domestic staff are facing problems as most are migrants and don't have bank accounts. Students of Science, Technology, Engineering and Management (STEM) and also the CSR Wings of Companies and Non-Profit organizations can play a catalytic role in this digital transformation. Some steps by which we can help them to adapt to the cashless system are (1) Open a JanDhan Account (2) Get Valid ID Proof (3) Use e-wallets to transact (4) Save for emergencies and (5) Invest in small instruments.

[NOTE: Jamshedpur Women's College's (JWC) Initiative ----The JWC has received the maximum number of registrations for an awareness campaign on digital transactions, initiated by the Union Ministry of Human Resources Development (MHRD) post demonetization. The MHRD has adjudged the Steel City College ahead of others, after it enrolled 1597 volunteers in a span of six days, beating Graphics Era Hill University of Dehradun and National College, Trichy with 1161 and 818 volunteers, who came second and third on the list respectively. "Indeed, it is an achievement for the college", said JWC Principal Shukla Mohanty who informed that the MHRD had launched the month long Vittiya Saksharta Abhiyan (VISAKA) in the University and colleges to train students for the cashless awareness campaign.] *

*Source: The Times of India, Ranchi Edition, dated December 20, 2016

\section{TIME FOR BUSINESS TO AVAIL OF E-COMMERCE SOLUTIONS:}

With the whole nation's focus increasingly shifting towards a cashless economy, it is time for business owners to get own online business portal. Services like those from GetMeAShop.com and others provide a 360-degree e-commerce solution for your business to help you find more customers. A Delhi launch is expected soon of an app for cashless transactions that uses a buyer's fingerprint and bank-linked Aadhaar number. The App works in the following manner:-

\section{How the app works?}

\begin{tabular}{|l|l|}
\hline Steps & Working Methodology \\
\hline Step-1: & $\begin{array}{l}\text { Once the merchant registers, he gets an SMS with a link he has to click to download the app. } \\
\text { In the first phase, a team will visit the merchant and train him. }\end{array}$ \\
\hline Step-2: & $\begin{array}{l}\text { This allows any customer who has Aadhaar linked bank accounts (AEPS, i.e. Aadhaar } \\
\text { Enabled Payment System) to pay with just two fields: bank name and Aadhaar number. Buyer } \\
\text { will pay from bank he picks from drop down. }\end{array}$ \\
\hline Step-3: & The buyer has to punch details of bank and Aadhaar number into seller's phone. \\
\hline Step-4: & Password is a person's fingerprint, which is virtually full proof till date. \\
\hline
\end{tabular}

\section{PSU BANKS - BOLD MOVE FOR CASHLESS \& DIGITAL:}

State Bank of India's arm is planning to come out with credit cards for anyone who has a Rs. 25,000 fixed in any bank. The card will not have any charges and will be available without any proof of income or a credit history. The bank's subsidiary, SBI Cards, also plans to issue credit cards to students of top 100 
educational institutions in India without any income proof. Besides servicing shops without machines, that bank will launch an app which will enable offline card payments via QR Code. The credit card will reside in the mobile and by scanning the code the cardholder can make the payment. This is a very innovative and noble approach by the PSU Bank towards smooth transition to Cashless Payment System and delivering superior Service to Customers.*

*Source: The Times of India, Ranchi Edition, dated December 22, 2016

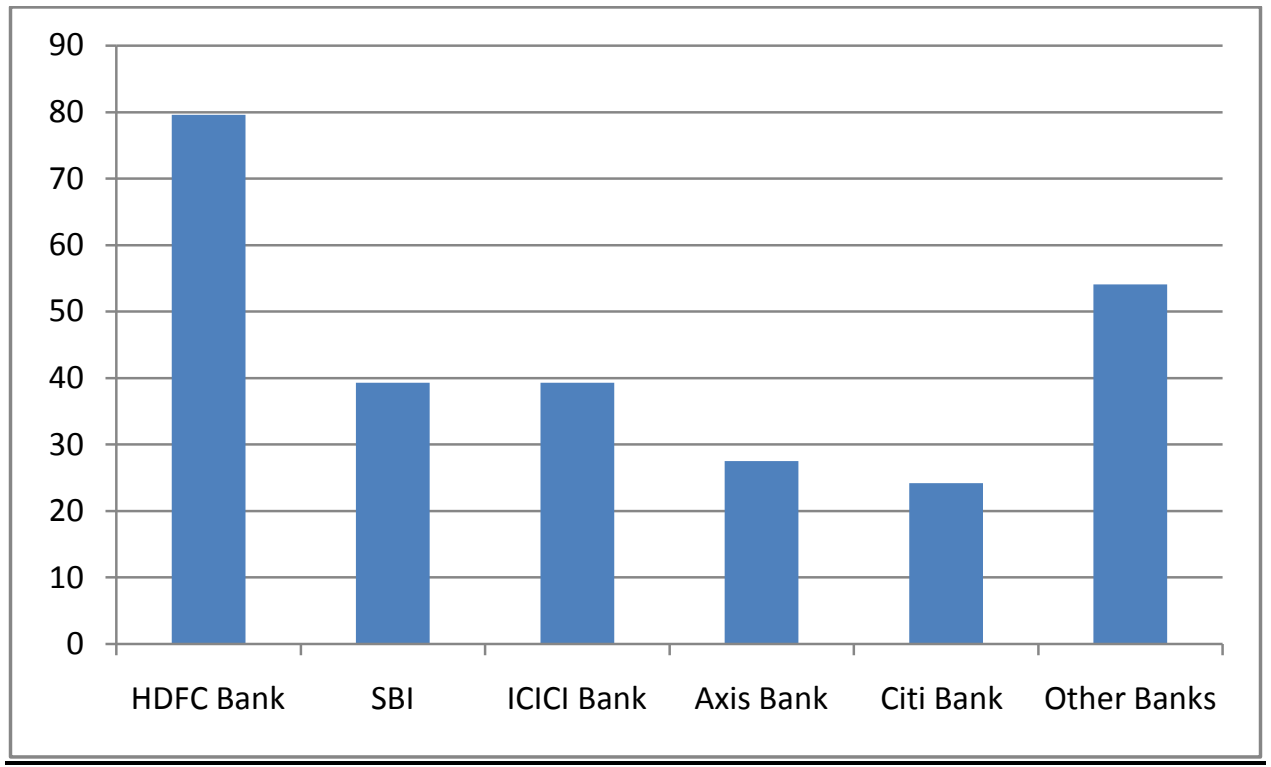

** Source: RBI-Consumers Using Plastic Money (No. of Cards in Lakhs)

\section{CONCLUSION:}

Banks in the world are the vital force behind the economic empowerment and are national growth engines. Since 1990s when Indian Government launched its ambitious plans to liberalize, privatize and globalize (LPG) our economy, things have changed at a rapid pace. The world have become more connected, with the rise of trade blocks in different parts of the world, including but not limited to NAFTA, SAFTA, ASEAN, OPEC, OECD, SAARC, EU, CIS and the like. The Central Banks of the Nations and important lenders of the world like Federal Reserve of USA, European Commercial Bank (ECB), Asian Development Bank (ADB), International Bank for Reconstruction and Development (IBRD), RBI in India and other prominent banks have been trying their best for a unified economic world with equal growth opportunities for all the stakeholders. Of late, BRICS Development Bank has been created with generous funding from giant economies like Brazil, Russia, India, China and South Africa, headquartered in Shanghai and having on board Mr. Deepak Parekh, Chairman, HDFC as its first ever CMD (Chairman \& Managing Director). It is sincerely hoped that this amalgamation and unification of Central Banks of the world will pave the way for a better utilization of resources and creation of a new world order free of hunger, malnutrition and underdevelopment. The SERVQUAL Model has now become more important instrument with which banks needs to calibrate their service operations. And the latest Demonetization drive by Indian Government and the shift towards Cashless Payment System are expected to go a long way in fulfilling these ambitions of commoners and socio-economic-political elites alike. We hope that this Digital Revolution will bring our dreams into a reality. It is also believed that Research in this field should be continued for searching out more universal economic principles and the need for calibration and recalibration mechanisms of the banking operations on a global basis for establishing a peaceful, productive, humane and happy world for everyone on Earth. 


\section{REFERENCES:}

[1]. Asubonteng, P., McCleary, K J., \& Swan, J E. (1996), SERVQUAL Revisited: A Critical Review of Service Quality, The Journal of Services Marketing, 10(6), pp. 62-81.

[2]. Bedi M (2010), “An Integrated Framework for Service Quality, Customer Satisfaction and Behavioral Responses in Indian Banking Industry - A Comparison of Public and Private Sector Banks", Journal of Services Research, Vol. 10, No. 1, pp. 157-172.

[3]. Choudhury K (2004), "The Influence of Customer-Perceived Service Quality on Customers' Behavioral Intentions", FPM Thesis Paper, Indian Institute of Management Calcutta.

[4]. Carman, J M (1990), Consumer Perceptions of Service Quality: An Assessment of the SERVQUAL Dimensions, Journal of Retailing, 66(1), pp. 33-51.

[5]. Cronin, J J and S A Taylor (1992),"Measuring Service Quality: A reexamination and Extension" Journal of Marketing, Vol. 53, No. 3, pp. 55-68.

[6]. Gronroos, C (1984), “A Service Quality Model and its Marketing Implications”, European Journal of Marketing, Vol. 18, No. 4, pp. 36-44.

[7]. Johnston, R (1995), The Determinants of Service Quality: Satisfiers and Dissatisfiers, International Journal of Service Industry Management, 6(5), pp. 53-71..

[8]. Malhotra N K, (1993), "Marketing Research: An Applied Oriented”, Prentice-Hall, Englewood Cliffs, NJ.

[9]. Manimaran S. (2010), "Linkage Between Service Quality and Customers' Loyalty in Commercial Banks", Journal of Marketing \& Communication, Vol. 6, Issue 1, pp. 26-34.

[10]. Mathur G., Chakraborty A., Vigg S. and Holani U. (2008), "Service Quality Perception of Corporate towards Private and Public Banks", Journal of Marketing \& Communication, Vol. 4, Issue 1, pp. 3747.

[11]. Parasuraman, A (2004). Assessing and Improving Service Performance for Maximum Impact: Insights from a Two-Decade-Long Research Journey, Performance Measurement and Metrics, 5(2), pp. $45-52$.

[12]. Parasuraman, A; A V Zeithaml and L L Berry (1985),"A Conceptual Model of Service Quality and its Implications for Future Research", Journal of Marketing, Vo. 49, No. 4, Fall, pp. 41-50.

[13]. Vanniarajan T and Nainamohamed K (2008), "Mapping Service Quality in the Indian Banking Industry", Journal of Marketing \& Communication, Vol. 4, Issue 1, pp. 23-36.

[14]. Zeithaml V A, Berry L L, and Parasuraman A, (1996), "The Behavioral Consequences of Service Quality", Journal of Marketing, 60(2), pp. 31-46. 


\footnotetext{
Authors' Profile:

Sumanta Mukhopadhyay did B.Sc.(Agriculture) and M.Sc. (Agriculture) from BCKV Agricultural University in West Bengal and MBA in Marketing\& Finance from NIT-D (National Institute of Technology -Durgapur). He did Executive Education from Indian Institute of Management, Calcutta(IIM-C) and Digital Marketing from DMI - Ireland. He also did Business English Certification (BEC) from University of Cambridge. He has 5 years of Research Experience in Management from NITDurgapur. He has written a book on Entrepreneurship and Cooperative Management and he regularly attends various seminars and workshops and his paper has been accepted in a Singapore Conference by Asian Institute of Research. He writes papers in national and international journals. He has been an Assistant Professor - Marketing in DSMS Group of Institutions Durgapur \& DSMS Business School. He also worked as Academic Coordinator, Zain Management Academy, Jamshedpur, and Associate Consultant in Education with MITCON Consultancy \& Engineering Services Pvt. Ltd. Presently he is an Educational Consultant, NIIT (National Institute of Information Technology), Durgapur Chapter, NIIT Imperia.
} 